\title{
ANALYSIS OF THE PRODUCTIVITY OF UPLAND RICE AND COVER CROPS IN RELAY INTERCROPPING SYSTEMS USING A MECHANISTIC COMPETITION MODEL
}

\author{
R. AKANVOU ${ }^{1}$, L. BASTIAANS ${ }^{2}$, M.JKROPFF ${ }^{2}$ et M. BECKER ${ }^{3}$ \\ ${ }^{1}$ CNRA 07 B.P 13 Abidjan 07, Côte d'Ivoire reneakanvou@yahoo.fr \\ ${ }^{2} \mathrm{PO}$ Box 430, 6700 AK Wageningen, The Netherlands \\ ${ }^{3}$ Institute of Agricultural Chemistry (ACl), University of Bonn, Karlrobert-kreiten-Str. 13, 53127 Bonn, Germany
}

\begin{abstract}
Relay intercropping systems with rice cultivars (WAB450-24-3-2-P18-HB (V4) and WAB56-50), the competitive Cajanus cajan and the weakly competitive Stylosanthes hamata were evaluated in the tropical savanna zone in Côte d'Ivoire. The INTERCOM model for competition served for data analysis and understanding of the system based on phenological, physiological and morphological characteristics of the species. Relationships between accumulated legume biomass and yield loss $(\mathrm{YL})$ in rice showed that rice yield was reduced up to $63 \%$ and $100 \%$ by S. hamata and C. cajan respectively, depending on the introduction time. At low levels of $\mathrm{YL}$ both legumes performed similarly. At higher levels of rice $\mathrm{YL}, \mathrm{C}$. cajan performed better as it produced higher amounts of biomass. Differences in legume biomass at a specified level of rice YL were mainly created in the growth period following rice maturity, which is restricted by water availability. The lesser performance of $S$. hamata in that period was attributed to the difference in phenology, combined with the short-duration character of the species. The combination of early introduction and short growth duration of this species prevented a rapid leaf canopy development after rice harvest, resulting in the relatively poor biomass production. Options to improve legume biomass production in relay systems should focus on the period following rice maturity.
\end{abstract}

Key-words : Legumes, cropping systems, yield loss, Côte d'lvoire.

\section{RESUME}

ANALYSE DE LA PRODUCTIVITE DU RIZ DE PLATEAU ET DES PLANTES DE COUVERTURE DANS UN SYSTEME DE CULTURE RELAIS A L'AIDE D'UN MODELE DE COMPETITION MECANISTIQUE.

Les systèmes de culture relais avec les variétés de riz (WAB450-24-3-2-P18-HB (V4) et WAB56-50), les espèces compétitives Cajanus cajan et faiblement compétitive Stylosanthes hamata, ont été évalués en zone savane tropicale de Côte d'lvoire. Le modèle de compétition INTERCOM a servi à l'analyse et à la compréhension du système sur la base des caractères phénologiques, physiologiques et morphologiques des espèces. La relation entre la production en biomasse des légumineuses et les pertes en rendement (PR) du riz ont montré que les rendements en riz ont été réduits de $63 \%$ et $100 \%$ par $\mathrm{S}$. hamata et $\mathrm{C}$. cajan, respectivement, en fonction de la date de semis. A de faibles niveaux de $P R$ en riz, les deux espèces de légumineuses se comportent de façon similaire. A des niveaux élevés de PR, C. cajan est plus performant en produisant des quantités de biomasse plus importantes. Les différences de production en biomasse à un niveau spécifié de perte de rendement en riz apparaissent principalement pendant la période suivant la maturité du riz et qui est restreint par la disponibilité en eau. La faible performance de $\mathrm{S}$. hamata pendant cette période est attribuée à la différence de phénologie, associée au caractère cycle court de cette espèce. La combinaison entre le semis précoce et le temps de croissance réduit n'a pas permis un développement rapide de la canopée après la récolte du riz, entraînant une production relativement mauvaise de la biomasse. Des options pour améliorer la production de biomasse des légumineuses dans les systèmes de culture relais doivent se focaliser sur la période suivant la maturité du riz.

Mots clés : Légumineuses, systèmes de culture, perte de rendement, Côte d'lvoire. 


\section{INTRODUCTION}

Intercropping is widely used in Latin America, Asia and Africa as a means for production of food and feed crops. It may involve all mixtures of annual and perennial crops. According to Fageria (1992), who reviewed the importance of multiple cropping systems and crop yield, intercropping systems comprise various methods which include mixed cropping, row intercropping, strip cropping, relay cropping and alley cropping. The relay intercropping system is a system which consists of growing two or more crops simultaneously, during part of the life cycle of each of the crop (Vandermeer, 1989). In weed management, the success of using intercropping as a strategy to control weeds is based on an efficient way of resource capture by desired plants in time and in space (Willey, 1979 ; Liebman and Dyck, 1993). For the resource light, this is achieved by minimizing the proportion reaching the soil through an increased interception of light by the mixed crop canopy (e.g., Baumann, 2001). Generally, a relay intercropping system consists of a main crop which is sown first and a secondary crop. The system can therefore be managed according to farmer's production objectives by varying sowing density and relative introduction time of the second crop to minimize yield reduction in the main crop. The main objective of relay cropping rice and cover crops is to obtain large amounts of accumulated $\mathrm{N}$ by the legume biomass that may improve soil quality in the following years without loosing much rice yield in the current year. This approach necessitates an optimum management of the system. Empirical evaluation of optimum combinations and establishment dates is extremely complex because of competition that takes place among plants. Descriptive models are often used to quantitatively characterize the outcome of competition. The yield loss - weed density model of Cousens (1985) or the relative leaf area model (Kropff and Spitters, 1991) was used to describe yield reduction of crops due to weeds. In relay cropping systems of rice and cover crops, rice yield loss was described by a logistic function of the relative sowing date of the component cover crop (Akanvou et al., 2002). However, because of a year to year variation in climatic conditions dynamic simulation models for competition seem an appropriate approach for a better understanding of the complex interactions that occur in rice-legume relay intercropping systems. Using that approach, morphological and physiological species characteristics, combined with management options such as sowing density and relative introduction time, are integrated to analyse the outcome of competition as observed in a well selected small number of experiments. Using the interplant competition model (INTERCOM), Kropff and van Laar (1993) determined that important characteristics, which confer competitive ability in e.g. sugar beet, were the early growth of leaf area and the earliness of height development. Similar findings have been reported in rice and maize as well (Bastiaans et al., 1997 ; Cavero et al., 2000). Baumann (2001) combined mechanistic and descriptive models for resource competition to analyse, explore and optimize a leek-celery intercropping system. He summarized simulations results by using a simple descriptive model for resource competition (Spitters, 1983) which allowed evaluation of the intercropping system in terms of productivity, crop quality and weed suppressive ability.

In the current study, a combination of mechanistic and descriptive models will be used for analysis of the upland rice-cover crop relay intercopping system. In addition, rice and legume models will be combined to analyse competition in relay intercropping systems. Possibilities for combining the production of a substantial amount of legume biomass with a marginal reduction in rice yield will be explored and the main determinants of a successful relay intercropping system will be identified.

\section{MATERIALS AND METHODS}

\section{FIELDEXPERIMENT}

Field experiments, comprising monocultures of two rice cultivars, two cover crop species and their mixtures at a range of relative introduction times of the cover crops, were conducted for three years during the wet season at the main research station of the Africa Rice Center (WARDA) in Côte d'Ivoire $\left(7^{\circ} 52^{\prime} \mathrm{N}, 5^{\circ} 06^{\prime} \mathrm{W}\right)$. This site is located in the savanna zone characterized by a cumulative annual rainfall of about $1000 \mathrm{~mm}$. The soil is classified as an Alfisol type with a sandy clay loam texture. The experiment was set-up as a randomized complete block design with three replications. 
It comprised factorial treatments of two rice cultivars (Oryza sativa variety WAB56-50 and WAB450-24-3-2-P18-HB (V4), which is an improved progeny of a cross between $O$. sativa and $O$. glaberima), by two legume species (Cajanus cajan (tall, fast-growing) and Stylosanthes hamata (short, slow-growing)), by four relative sowing dates of the legumes. Pure stand treatments of the rice cultivars (2) and legume species $(2 \times 4$ sowing dates) were added. The relative sowing dates were set to 0 , 14,28 and 56 DARS as it was found that after 56 DARS rice yield was hardly affected. Individual plots measured $6 \mathrm{~m} \times 4 \mathrm{~m}$. In monoculture, rice was dibble-seeded at $0.25 \mathrm{~m} \times 0.20 \mathrm{~m}$ spacing and thinned after three weeks to 60 plants $\mathrm{m}^{-2}$ (3 plants per hill). C. cajan was sown using the same arrangement as in rice but at a density of 40 plants $\mathrm{m}^{-2}$ (2 plants per hill). S. hamata was established at 160 plant $\mathrm{m}^{-2}$ (2 plants per hill) using a spacing of $0.125 \mathrm{~m} \times 0.100 \mathrm{~m}$. Plots were kept weed free by hoeing. Land was ploughed and fertilized with $30 \mathrm{~kg} \mathrm{P}$ (triple super phosphate) and $34 \mathrm{~kg}$ $\mathrm{K}(\mathrm{KCl})$ at field preparation and with $30 \mathrm{~kg} \mathrm{ha}^{-1}$ of urea-N, applied at 30 days after rice sowing. The soil was well drained and moisture not limiting due to supplementary overhead-boom irrigation. Measurements were conducted every two weeks. A stick measurement of plant height was recorded in the field from soil surface to the top of the plant. Destructive samplings were taken on $0.40 \mathrm{~m}^{2}$ areas. Dry weight was determined from oven-dried materials at $70{ }^{\circ} \mathrm{C}$ for 48 hours. Plants were separated into leaves, stems and storage organs to determine the partitioning of dry matter to the various above ground organs. Leaf area index (LAI) was determined from leaf sub-samples using an LAI meter (Licor 3000).

\section{MODELDESCRIPTION}

The model INTERCOM was used to simulate and analyse growth of the crops in the ricelegume relay intercropping system. INTERCOM basically constitutes of a number of crop growth models equal to the number of competing species, which are linked through additional subroutines that account for the distribution of resources (light, water and nutrients) over the competing species (Kropff and van Laar, 1993). The component growth models are based on SUCROS (Goudriaan and van Laar, 1994 ; Bouman et al., 1996) a carbohydrate driven model, which simulates the dry matter increase over time, based on crop specific parameters and weather data, using a time step of one day. In the current study, water and nutrients were assumed non-limiting to the rice and the legume species ; therefore, only competition for light was considered. Competition for light is simulated as an instantaneous process of resource capture. The efficiency of resource capture is related to the light absorption characteristics of a species, which are related to leaf thickness, leaf angle distribution, LAI and vertical leaf area density profile. These characteristics as well as leaf area are implicitly accounted for in the light extinction coefficient (k), and included in the calculation of light interception of monoculture models. The vertical leaf area density profile is not included in these models, as for simulation of light interception in monocultures, only the amount and not the vertical distribution of leaf area is relevant. In species mixtures, however, the situation is different, and the vertical leaf area density profile has to be specified to enable the calculation of light capture at different heights in the canopy. In INTERCOM this is realized by coupling a dynamic description of plant height development to a static standard function of vertical leaf area distribution. Plant height development $\left(\mathrm{h}_{\mathrm{ts}} ; \mathrm{m}\right)$ is described by a logistic function using temperature sum (ts; ${ }^{\circ} \mathrm{Cd}$ ) as driving variable :

$$
h_{\mathrm{ts}}=h_{\max } /\left(1+h_{\mathrm{b}} e-h_{\mathrm{s}} t s\right)
$$

where $h_{b}$ and $h_{s}$ are coefficients defining the shape of the function and $h_{\text {max }}$, the maximum height of the species $(\mathrm{m})$, operates as a scaling factor. Early height growth is determined by $h_{s}$ $\left({ }^{\circ} \mathrm{Cd}\right)^{-1}$.

\section{PARAMETERIZATION OF THE MODELS}

The rice monoculture treatments were used for parameterization and calibration of the rice monoculture models. In the model, the phenological development stage (DVS) of the rice crop was defined by a value of 0 at emergence, 1 at flowering and 2 at maturity. The temperature sum required to reach flowering and maturity was calculated using a base temperature of $8{ }^{\circ} \mathrm{C}$ (Kropff et al., 1994). Leaf area expansion during early growth stages was described by an exponential curve of leaf area observations until a LAI of 1 . The rate of expansion was determined by the relative leaf area growth rate $\left(\mathrm{RGRL},\left({ }^{\circ} \mathrm{Cd}\right)^{-1}\right)$ and the apparent leaf area per plant at emergence $\left(\mathrm{LA} 0, \mathrm{~m}^{2}\right.$ plant $\left.^{-1}\right)$. After the exponential growth 
phase, leaf area is simulated by multiplying the increase in dry weight by the specific leaf area of newly formed leaves $\left(S L A_{\text {new }}\right)$. The development rates $\left({ }^{\circ} \mathrm{Cd}\right)^{-1}$ were calculated as the inverse of the period required to proceed from emergence to flowering (vegetative development rate, DVRV) and from flowering to maturity (reproductive development rate, DVRR). After parameterization, the models were calibrated in a two step procedures using observed data on leaf area development and shoot dry matter production as a reference.

For the two legume species, C. cajan and $S$. hamata, the parameterization and calibration procedure of the monoculture models was conducted in the same way and the procedure and results have been described (Akanvou, 2001). Apart from monoculture models of the component crops, the competition model INTERCOM contains additional routines for the distribution of light over the competing species. In INTERCOM this is realized by coupling a dynamic description of plant height development to a standard function of vertical leaf area distribution. A parabolic function was used to describe the vertical leaf area distribution (Kropff and van Laar, 1993).

\section{EVALUATION OF THE RICE-COVER CROP COMPETITION MODEL}

Competition models were derived by combining the monoculture models of rice with the monoculture models of the cover crops. Evaluation of these competition models was done by comparing simulated and observed rice and legume biomass at rice harvest for all introduction times of the cover crops. In an earlier analysis of the field experiments, it was observed that both final rice and legume biomass could be described by a logistic function of relative sowing date of the cover crop (Akanvou et al., 2002). Therefore, simulated rice and legume biomass of each rice-legume combination $\left(Y_{r}\right.$ and $Y_{1}$, respectively ; $\mathrm{kg} \mathrm{ha}^{-1}$ ) were fitted against relative sowing date of the cover crop ( $t$; days after rice sowing) using a logistic equation :

and

$$
Y_{\mathrm{r}}(t)=\frac{Y_{\mathrm{r}, \max }}{1+b_{\mathrm{r}} \exp -_{-\mathrm{r} t}}
$$

$$
Y(t)=\frac{Y_{1, \max }}{1+b_{1} \exp -_{c 1 t}}
$$

in which $\mathrm{Y}_{\max }=$ maximum produced biomass $(\mathrm{kg}$ $\left.\mathrm{ha}^{-1}\right)$, and $\mathrm{b}(-)$ and $c\left(\mathrm{~d}^{-1}\right)$ are parameters describing the logistic equation. The non-linear regression option of GENSTAT was used to obtain the best fitting logistic functions. For rice the maximum produced biomass at harvest was set to the value obtained in monoculture, and consequently only the parameters $b$ and $c$ were estimated. The logistic functions were plotted against the relative sowing date of the cover crop and compared with observed data to assess model performance. The evaluation of the competition models was conducted in two steps. In the first step, simulation runs with the model were conducted using observed leaf area and plant height for both species. In a second step leaf area and plant height were simulated, and the model evaluation could be focused on the simulation of these morphological features.

\section{ANALYSIS OF THE RICE-COVER CROP INTERCROPPING SYSTEM}

Suitability of a rice-legume combination is determined by its ability to produce a reasonable amount of legume biomass at the cost of only a marginal loss in rice yield. To enable a proper evaluation of the various rice-legume combinations, simulated loss in rice grain yield was expressed as a function of simulated legume biomass. For this purpose, similar to rice and legume biomass, simulated rice grain yield was fitted to a logistic function of relative sowing date of the cover crop, using the non-linear regression option of GENSTAT. Equation (3), describing the relation between legume biomass and relative introduction time of the cover crop, was then rewritten to :

$$
t=-\frac{\ln \left(\frac{Y_{1, \text { max }} / Y_{1}(t)-1}{b_{1}}\right)}{c_{1}}
$$

and introduced in equation (2):

$$
Y_{\mathrm{r}}(t)=\frac{Y_{\mathrm{r}, \text { max }}}{1+b_{\mathrm{r}} \exp _{-c_{\mathrm{r}} t}}=\frac{Y_{\mathrm{r}, \text { max }}}{1+b_{\mathrm{r}} \exp \left(c_{\mathrm{r}}\left(\ln \left(\left(Y_{1, \max } / Y_{\mathrm{l}}(t)-1\right) / b_{\mathrm{l}}\right) / c_{\mathrm{l}}\right)\right)}
$$

This could then be rewritten to obtain a relation between rice yield loss (YLr) and legume biomass :

$$
Y L_{\mathrm{r}}=1-\frac{Y_{\mathrm{r}}(t)}{Y_{\mathrm{r}, \text { max }}}=1-\left(\frac{1}{1+b_{\mathrm{r}} \exp \left(c_{\mathrm{r}}\left(\ln \left(\left(Y_{1, \text { max }} / Y_{1}(t)-1\right) / b_{1}\right) / c_{1}\right)\right)}\right)_{(6)}
$$

In the field experiment, rice and legumes were harvested at about one week after physiological maturity of the rice. For a further analysis of the relay intercropping system, simulated legume biomass both at rice maturity and at three weeks thereafter, corresponding to a conservative estimate of the length of the period in which water availability still allows for a period of extended growth, were determined. Differences in 
simulated legume biomass between $C$. cajan and $S$. hamata were then explained in terms of differences in legume biomass at maturity of rice and differences in legume biomass production in the period following rice maturity. These last differences were then assigned to differences in starting position of the legumes at rice maturity, particularly LAI and development stage, and differences in growth characteristics of the legumes. This last analysis was performed by conducting additional simulations for the final three weeks of legume growth after gradually replacing the starting position, particularly LAI and phenological development, of $C$. cajan at rice maturity by that of $S$. hamata and vice versa. The level of difference between simulation results after replacement of a specific characteristic then reflects the contribution of the specific factor for the overall difference. In this simulation study, rice cultivar V4 was used and differences in productivity of $C$. cajan and $S$. hamata were compared at rice yield reductions of 5, 10 and $20 \%$. In a final analysis, height growth characteristics of $C$. cajan and $S$. hamata were exchanged to further explore the outcome of using highly and weakly competitive legume species in rice-legume relay intercropping.

\section{RESULTS}

\section{MONOCULTURE MODELS}

Models for growth of rice and the cover crops in monoculture were parameterized and validated in an earlier study (Akanvou, 2001). Table 1 presents the summary of the parameter estimates for the two rice cultivars V4 and WAB56-50. Values for the developmental rates for the vegetative (DVRV) and the reproductive (DVRR) periods were identical as both cultivars flowered and matured at the same time. Value of SLA ${ }_{\text {new }}$ of the cultivars fluctuated around 23 $\mathrm{m}^{2} \mathrm{~kg}^{-1}$, with the values for V4 slightly higher than for WAB56-50 during the first part of development (Table 1). Partitioning coefficients of dry matter over shoot and root were kept identical to Kropff et al. (1994), whereas the time course of partitioning over leaves, stems and storage organs was derived from field observations. Results for both cultivars were nearly the same (Figure 1).

The observed time course of plant height for the rice species and the two cover crop species was accurately described by a logistic function of thermal time $\left({ }^{\circ} \mathrm{Cd}\right)^{-1}$ after emergence. Correlation coefficients surpassed 0.96 whereas residual variance was homogeneously distributed over the fitted curves. In Table 2, parameters describing the logistic increase in height are summarized. V4 and WAB56-50 had similar maximum height, and a similar relative height growth rate $\left(\mathrm{H}_{\mathrm{s}}\right)$. The slightly postponed development of WAB56-50 was reflected in a higher $\mathrm{H}_{b}$ value. Values for $S$. hamata were nearly similar to rice except for maximum height, which was only $92 \mathrm{~cm}$. Height development for $C$. cajan was clearly the fastest as both relative height growth rate and maximum height surpassed those of $S$. hamata and the two rice cultivars.

Table 1 : Summary of the parameter estimates for the two rice cultivars V4 and WAB56-50.

Résumé des estimations des paramètres des deux cultivars de riz V4 et WAB56-50.

\begin{tabular}{|c|c|c|c|c|}
\hline \multirow{2}{*}{ Value or function description } & \multirow{2}{*}{ Acronyms } & \multirow{2}{*}{ Units } & \multicolumn{2}{|c|}{ Cultivars de riz } \\
\hline & & & V4 & WAB56-50 \\
\hline Development rate during vegetative phase & DVRV & $\left({ }^{\circ} \mathrm{Cd}\right)^{-1}$ & 0.000848 & 0.000848 \\
\hline Development rate during reproductive phase & DVRR & $\left({ }^{\circ} \mathrm{Cd}\right)^{-1}$ & 0.00154 & 0.00154 \\
\hline Light extinction coefficient for leaves & $\mathrm{KDF}$ & \multirow[b]{2}{*}{$\mathrm{kg} \mathrm{CO} 2 \mathrm{ha}^{-1}$ leaf $\mathrm{h}^{-1}$} & 0.6 & 0.6 \\
\hline Photosynthetic rate & AMAX & & $\begin{array}{c}0,54 ; 1000,45 \\
1200,12 ; 2000,6\end{array}$ & $\begin{array}{c}0,54 ; 1000,42 \\
1200,18 ; 2000,9\end{array}$ \\
\hline Dry matter distribution pattern & & & Fig. 1 & Fig. 1 \\
\hline above ground (leaves-stems-panicles) & & & - & - \\
\hline Relative growth rate of leaf area & RGRL & $\left({ }^{\circ} \mathrm{Cd}\right)^{-1}$ & 0.0073 & 0.0076 \\
\hline Initial leaf area & LAO & & 0.0000868 & 0.0000163 \\
\hline \multirow{3}{*}{ Death rate } & \multirow{3}{*}{ RDRLV } & \multirow{3}{*}{$\mathrm{m} 2$ plant $^{-1}$} & 1179,$0 ; 1445,0.0052$ & 921,$0 ; 1179,0.0099$ \\
\hline & & & $\begin{array}{l}1782,0.033 \\
2000,0.033\end{array}$ & $1445,0.0025 ; 1782,0.033$ \\
\hline & & & & $2000,0.033$ \\
\hline \multirow{4}{*}{ Specific leaf area } & \multirow{4}{*}{ SLA } & \multirow{4}{*}{$\mathrm{m} 2 \mathrm{~kg}^{-1}$} & $0,22.6 ; 148,22.6$ & $0,18.3 ; 148,18.3$ \\
\hline & & & 218,$26 ; 420,26.4$ & $218,23.3 ; 420,25$ \\
\hline & & & 674,$18 ; 921,18$ & $674,18.7 ; 921,18$ \\
\hline & & & 1350,$25 ; 2000,25$ & 1350,$25 ; 2000,25$ \\
\hline
\end{tabular}

Functions in the table are related to thermal time $\left({ }^{\circ} \mathrm{Cd}\right)$.

Les fonctions dans le tableau sont en relation avec le temps thermal $\left({ }^{\circ} \mathrm{Cd}\right)$ 




Figure 1: The fraction of new dry matter partitioned among the different shoot organs as a function of thermal time for rice cultivars V4 ( ?? ) and WAB56-50 (----).

La fraction de nouvelles biomasse partitionnée entre les différentes parties de la plantule en fonction du temps thermal pour les cultivars de riz V4 (?? ) et WAB56-50 (----).

Table 2 : Estimated parameter values and standard errors in parenthesis using a logistic regression model to fit observed height over time.

Valeurs des paramètres et erreurs standards en parenthèses, estimés à l'aide d'un modele de régression logistique pour estimer les valeurs moyenne de hauteur observées au cour du temps.

\begin{tabular}{lcccc}
\hline Paramètres & V4 & WAB56-50 & C. cajan & S. hamata \\
\hline $\mathrm{H}_{\max }(\mathrm{cm})$ & $118(18)$ & $121(20)$ & $251(13)$ & $92(8)$ \\
$\mathrm{H}_{\mathrm{s}}\left({ }^{\mathrm{O}} \mathrm{Cd}\right)^{-1}$ & $0.0024(0.0007)$ & $0.0025(0.0008)$ & $0.0030(0.0003)$ & $0.0026(0.0003)$ \\
$\mathrm{H}_{\mathrm{b}}(-)$ & $14.5(8.0)$ & $23.6(18.2)$ & $23.9(5.5)$ & $22.5(4.5)$ \\
$\mathrm{r}^{2}$ & 0.96 & 0.97 & 0.99 & 0.99 \\
\hline
\end{tabular}

\section{EVALUATION OF THE RICE/COVER CROP COMPETITION MODELS}

In Figure 2, results of $C$. cajan in competition with both rice cultivars are presented. The figures indicate that by delaying the time of legume introduction, rice biomass increases while legume biomass gradually decreases. In general, the models gave adequate simulations of the observed field data both for rice biomass and accumulated legume biomass. In Figure 3, despite adequate simulations of $S$. hamata in monoculture, the simulation of competition of this legume with the two rice cultivars, using exclusively parameters from the monoculture of rice and S. hamata, was poor. The discrepancy between observed and simulated data was mainly found at 0,14 and sometimes 28 DARS. For the later dates of introduction, the rice completely out-competed the legume, both in the field and in the simulations. The models clearly underestimated the competitiveness of 
S. hamata, resulting in an overestimation of rice biomass. Further inspection of observed data indicated that in competition with rice, SLA of $S$. hamata increased compared to SLA in monoculture. To determine the consequences of an increased SLA, simulations were conducted in which the measured time course of $S L A_{\text {new }}$ of $S$. hamata in the mixture was included as an explicit function in the model. This resulted on average in a relative increase in biomass of about $15 \%$ in S. hamata while rice biomass was decreased by less than $2 \%$ for the introduction dates 0,14 and 28 DARS. Based on these results, a dynamic simulation procedure of SLA was included in the model to account for morphological adaptations of newly formed leaves of $S$. hamata as a result of shading by the rice crop. The introduced procedure was based on Cavero et al. (2000), and consisted of the determination of a shading stress index (SSI) which was calculated as the ratio between the photosynthetic active radiation (PAR) absorbed by the portion of the rice canopy located above the $S$. hamata plants and total incoming PAR. A multiplicative factor (MF) was derived from the ratio of SLA in mixture over that in monoculture and this factor was related to SSI (Figure 4). Accounting for the formation of thinner leaves as a result of shading was insufficient to explain the underestimation of competitive ability of $S$. hamata.

Based on field observations, the vertical leaf area distribution of $S$. hamata was adjusted in a more upward direction resulting in an increased competitiveness of this species. For this purpose, a lower boundary of $50 \%$ for leaves of $S$. hamata was defined as a fraction of actual plant height, while the parabolic leaf area distribution was maintained to obtain reasonable agreement between observed and simulated data (Figure 3). In this way the effect of competition for nitrogen was implicitly taken into account.
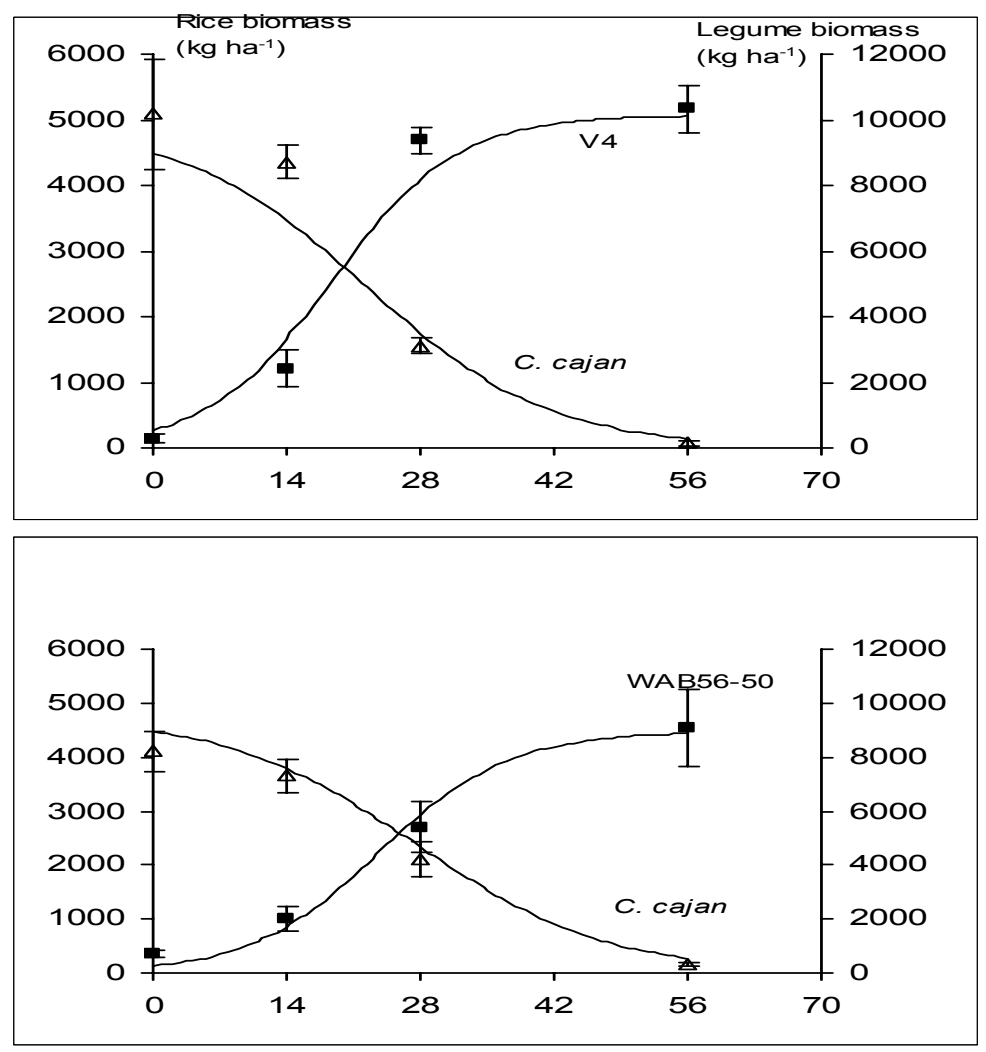

Days after rice sowing

Figure 2 : Comparison of simulated (lines) and observed (markers) final biomass of rice (V4 and WAB56-50) and C. cajan in competition at different sowing times.

Comparaison de la biomasse finale du riz et de C. cajan simulée (lignes) et observée (marques), en compétition à différents périodes de semis.

Simulated curves were derived after fitting the data to a logistic function. Bars represent standard errors of the observed values. Les courbes de simulation ont été obtenues après une courbe de tendance des données par une fonction logistique. Les bars représentent l'erreur standard des valeurs observées. 


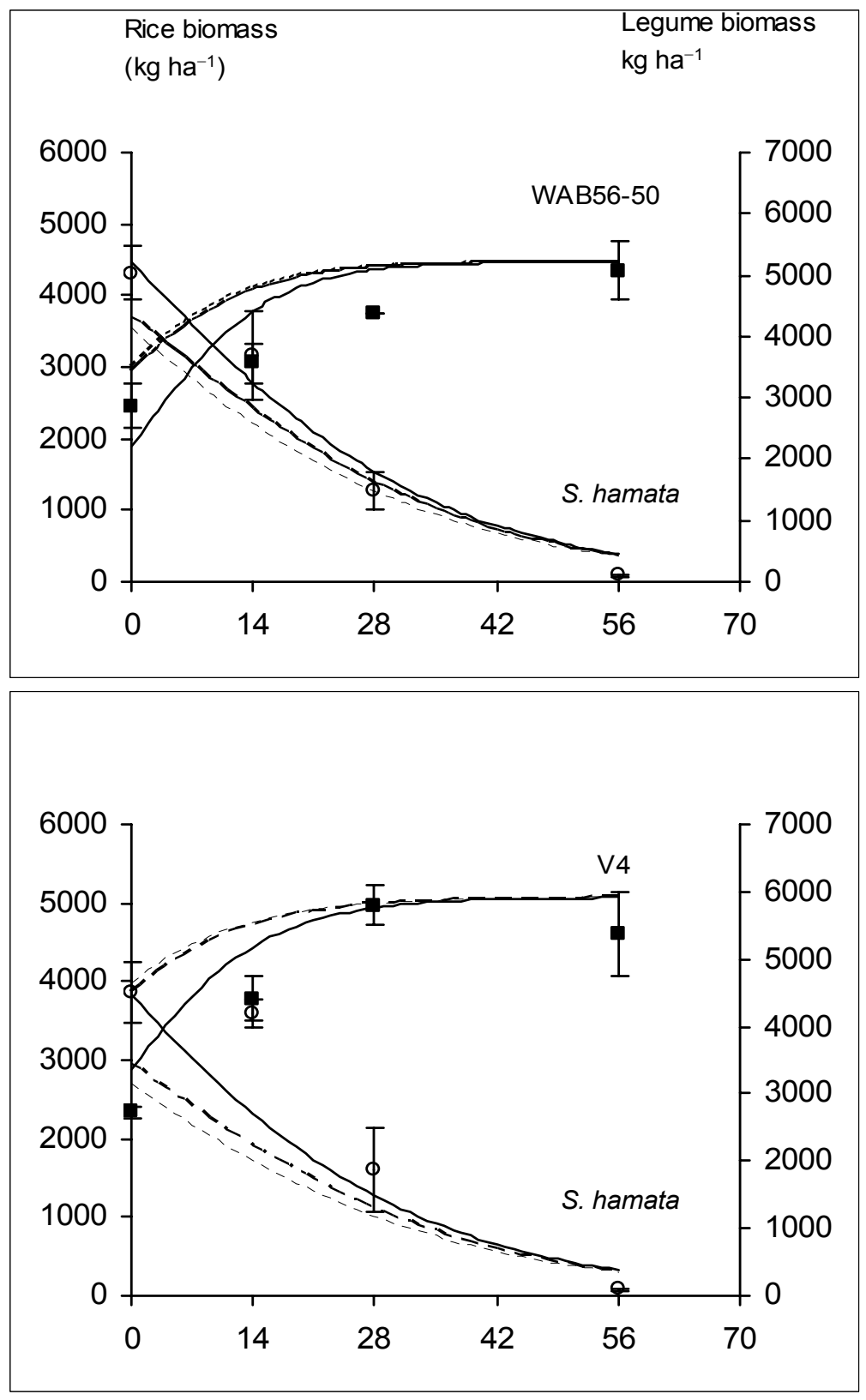

Days after rice sowing

Figure 3 : Comparison of simulated (lines) and observed (markers) final biomass of rice (V4 and WAB56-50) and $S$. hamata in competition at different sowing times. Simulated curves were derived after fitting the data to a logistic function. Bars represent standard errors of the observed values. The different lines represent simulation using SLA values from the monoculture (----), taking into account the effect of shade (- - -), and adding a coefficient to describe the lower boundary $(\mathrm{Ib}=0.5)$ of the canopy of $S$. hamata $\left(\_\right)$.

Comparaison de la biomasse finale du riz (V4 et WAB56-50) et de S. hamata simulée (lignes) et observée (marques), en compétition à différents périodes de semis. Les courbes de simulation ont été obtenues après une courbe de tendance des données par une fonction logistique. Les bars représentent l'erreur standard des valeurs observées. Les différentes lignes représentent les courbes de simulation avec des valeurs de surface foliaire specific SLA de la monoculture (----), en prenant en compte l'effet de l'ombrage (- - -), et ajoutant un coefficient pour décrire la limite inférieure $(\mathrm{Ib}=0.5)$ de la canopée de S. hamata ( $)$. 




Shading stress index

Figure 4 : Relationship between the shadıng stress ındex and the multiplicative factor of the specific leaf area (SLA) of S. hamata based on two-year data. Bars indicate standard errors of the mean.

Relation entre l'index d'ombrage et le facteur multiplicatif de la surface foliaire spécific (SLA) de S. hamata sur la base de deux années de données. Les bars indiquent l'erreur standard de la moyenne.

\section{ANALYSIS OF THE CROPPING SYSTEM}

The relationship between simulated loss in rice grain yield and accumulated legume biomass was generated by using equation (6). In Figure 5, only the simulated results are presented. At rice maturity, similar yield losslegume biomass relationships were obtained for all combinations of legume species and rice cultivars, though dates of legume introduction differed. Comparison of the open and the closed markers, which refer to an introduction time of 28 DARS, demonstrate that $C$. cajan is more competitive than S. hamata. Maximum yield loss caused by $S$. hamata was about $60 \%$ in V4 and $65 \%$ in WAB56-50, while $C$. cajan completely out-competed the two rice crops. At similar introduction dates both legume species produced slightly higher amounts of biomass in mixture with WAB56-50 compared to V4.

A further simulation analysis of the differences between the highly competitive $C$. cajan and the weakly competitive $S$. hamata was conducted using rice cultivar V4. At rice yield loss levels of
5,10 and $20 \%$, only small differences in simulated legume biomass at rice maturity were observed between both species (Table 3). To obtain these results the less competitive $S$. hamata had to be introduced between 16 to 19 days earlier, for yield reduction levels of 5 and $20 \%$, respectively (Table 3 ). Consequently, at rice maturity, phenological development of $S$. hamata expressed in degree-days was on average $250^{\circ} \mathrm{Cd}$ more advanced than that of $C$. cajan. At the same time, the less competitive S. hamata was allowed to have developed clearly more leaf area, most likely because competitive ability on a leaf area basis was smaller for $S$. hamata than for $C$. cajan. This difference was particularly obvious at a rice yield reduction of $5 \%$, whereas differences at $20 \%$ were only marginal. The consequences of these differences for legume biomass production in the three weeks following rice maturity were analysed by performing additional simulation runs for this specific period, in which characteristics of the starting position of both legumes at rice maturity, particularly phenology and LAI, were successively exchanged. If a rice yield reduction 
of only $5 \%$ was permitted, legume biomass production after three weeks was nearly the same, though for both legumes these yields were realized in a different way. Accumulated biomass of $S$. hamata at rice maturity was about $300 \mathrm{~kg} \mathrm{ha}^{-1}$ higher. Furthermore, this legume had a clearly higher $\mathrm{LAl}$ at rice maturity, resulting in a better light interception and an increased biomass production of around $570 \mathrm{~kg} \mathrm{ha}^{-1}$. On the other hand, phenological development of $S$. hamata was more advanced, resulting in a lower production of around $440 \mathrm{~kg} \mathrm{ha}^{-1}$ due to ageing, whereas the differences in growth characteristics were responsible for a $480 \mathrm{~kg} \mathrm{ha}^{-1}$ production deficit of S. hamata compared to C. cajan. Overall these effects counterbalanced one another resulting in nearly the same legume biomass production at three weeks after rice maturity. If larger rice yield losses were permitted, clear differences in simulated legume biomass production between $S$. hamata and $C$. cajan started to appear, and these differences enlarged with higher rice yield losses. In a final simulation analysis, height growth characteristics of $S$. hamata and $C$. cajan, specifically $\mathrm{H}_{\text {max }}, \mathrm{H}_{\mathrm{b}}$ and $\mathrm{H}_{\mathrm{s}}$, were mutually exchanged to create a competitive Stylosanthes and a weakly competitive Cajanus. At rice maturity striking similarities between the original C. cajan and the competitive version of S. hamata were observed (Table 4). Required introduction date as well as phenological development, LAI and accumulated biomass at rice maturity were largely identical. The additional growth in the three weeks period following rice maturity were also nearly the same, resulting in an identical overall legume biomass production. Comparison of simulation results obtained by using the original Stylosanthes and the weakly competitive version of Cajanus showed also clear similarities for characteristics like required introduction date, phenological development and LAI. However, marked differences were observed for biomass accumulation at rice maturity and additional growth in the three weeks following rice maturity, resulting in an overall difference in biomass accumulation of around $770 \mathrm{~kg} \mathrm{ha}^{-1}$ to the benefit of the weakly competitive version of $C$. cajan.

Table 3 : Summary of simulation results reflecting phenology and LAI of two relay-cropped legume species (C. cajan and S. hamata) in rice cultivar V4 at rice maturity for legume introduction dates that resulted in simulated rice yield losses of 5,10 and $20 \%$.

Synthèse des résultats de la simulation indiquant la phénologie et l'indice de surface foliaire de deux légumineuses (C. cajan and $\mathrm{S}$. hamata) semées en relais avec la variété de riz V4 à maturité, pour des dates de semis des légumineuses ayant aboutis à une simulation de perte de rendement en riz de 5, 10 et $20 \%$.

\begin{tabular}{|c|c|c|c|c|c|c|c|c|c|}
\hline Rice yield loss & & $5 \%$ & & & $10 \%$ & & & $20 \%$ & \\
\hline \multicolumn{10}{|c|}{ (2 } \\
\hline Day of introduction & 228 & 212 & - & 221 & 203 & - & 215 & 196 & - \\
\hline \multicolumn{10}{|l|}{ At Rice maturity } \\
\hline Phenological age $\left({ }^{\circ} \mathrm{Cd}\right)$ & 1053 & 1264 & - & 1177 & 1428 & - & 1282 & 1562 & - \\
\hline $\operatorname{LAI}\left(\mathrm{m}^{2} \mathrm{~m}^{-2}\right)$ & 1.33 & 2.1 & - & 1.79 & 2.34 & - & 2.55 & 2.68 & - \\
\hline A. Biomass at rice maturity $\left(\mathrm{kg} \mathrm{ha}^{-1}\right)$ & 985 & 1293 & -308 & 1615 & 1899 & -284 & 2599 & 2696 & -97 \\
\hline B. Additional growth $\left(\mathrm{kg} \mathrm{ha}^{-1}\right)$ & 2373 & 2074 & 299 & 2539 & 1722 & 817 & 2623 & 1407 & 1216 \\
\hline \multicolumn{10}{|l|}{ Differences $\left(\mathrm{kg} \mathrm{ha}^{-1}\right)$ attributed to: } \\
\hline Phenological age & - & - & 444 & - & - & 519 & - & - & 493 \\
\hline$L A I$ & - & - & -567 & - & - & -313 & - & - & -54 \\
\hline Legume growth characteristics & - & - & 478 & - & - & 667 & - & - & 783 \\
\hline Interaction & - & - & -47 & - & - & -56 & - & - & -6 \\
\hline A+B. Biomass 3 weeks after rice maturity & 3358 & 3367 & -9 & 4154 & 3621 & 533 & 5222 & 4103 & 1119 \\
\hline
\end{tabular}

Differences in simulated overall accumulated legume biomass at three weeks after rice maturity were attributed to differences in phenology, LAl and growth characteristics of both legumes.

Les différences entre la biomasse totale simulée à trois semaines après la récolte du riz sont dues aux différences de phénologie, d'indice de surface foliaire et des caractéristiques de croissance des deux légumineuses. 
Table 4 : Summary of simulation results reflecting phenology, LAI and height of two relay-cropped legume species (C. cajan and S. hamata) in rice cultivar V4 at rice maturity for legume introduction dates that resulted in a simulated rice yield loss of $10 \%$. Height growth characteristics of both legume species were exchanged to analyse the effect of competitive ability on legume performance. Differences in simulated overall accumulated legume biomass at three weeks after rice maturity were attributed to differences in phenology, LAI and growth characteristics of both legumes

Synthèse des résultats de la simulation indiquant la phénologie, l'indice de surface foliaire et la taille de deux légumineuses (C. cajan and $\mathrm{S}$. hamata) semées en relais avec la variété de riz $\mathrm{V} 4$ à maturité, pour des dates de semis des légumineuses ayant aboutis à une simulation de perte de rendement en riz de $10 \%$. Les caractéristiques de croissance en hauteur des deux espèces ont été échangées pour analyser les effets de la compétition sur la performance des légumineuses. Les différences entre la biomasse totale simulée à trois semaines après la récolte du riz sont dues aux différences de phénologie, d'indice de surface foliaire et des caractéristiques de croissance des deux légumineuses.

\begin{tabular}{|c|c|c|c|c|c|c|}
\hline & \multicolumn{3}{|c|}{ C. cajan } & \multicolumn{3}{|c|}{ S. hamata } \\
\hline & original & less competitive & differences & original & more competitive & differences \\
\hline Day of introduction & 221 & 202 & - & 203 & 222 & - \\
\hline \multicolumn{7}{|l|}{ At Rice maturity } \\
\hline Phenological age $\left({ }^{\circ} \mathrm{Cd}\right)$ & 1177 & 1523 & - & 1428 & 1085 & - \\
\hline $\operatorname{LAI}\left(\mathrm{m}^{2} \mathrm{~m}^{-2}\right)$ & 1.79 & 2.25 & & 2.34 & 1.86 & - \\
\hline \multicolumn{7}{|l|}{ Differences in biomass accumulation of the legumes } \\
\hline A. Biomass at rice maturity $\left(\mathrm{kg} \mathrm{ha}^{-1}\right)$ & 1615 & 2262 & -647 & 1899 & 1667 & 232 \\
\hline B. Additional growth $\left(\mathrm{kg} \mathrm{ha}^{-1}\right)$ & 2539 & 2132 & 407 & 1721 & 2390 & -669 \\
\hline \multicolumn{7}{|l|}{ Differences $\left(\mathrm{kg} \mathrm{ha}^{-1}\right)$ attributed to: } \\
\hline Development stage & - & - & 549 & - & - & -765 \\
\hline$L A I$ & - & - & -306 & - & - & 261 \\
\hline Height & - & - & 180 & - & - & -155 \\
\hline Interaction & - & - & -15 & - & - & -10 \\
\hline A+B. Biomass 3 wks after rice maturity $\left(\mathrm{kg} \mathrm{ha}^{-1}\right)$ & 4154 & 4394 & -240 & 3620 & 4057 & -437 \\
\hline
\end{tabular}

\section{DISCUSSION}

\section{SIMULATION ANALYSIS OF RICE-LEGUME INTERCROPPING}

Relay intercropping cover crops in upland rice in the tropical savanna zone of Côte d'Ivoire was analysed with two very contrasting leguminous species (C. cajan and S. hamata) using a mechanistic approach. The performances of the two species pointed out the role of light distribution in the systems. Late introductions of the legumes species particularly increased their specific leaf area (SLA) due to shading by the rice crop. The effects of shade on the morphophysiology of plants have implications on dry matter partitioning, height growth and leaf thickness (Hawkins, 1982; Kropff and Spitters, 1992 ; Cavero et al., 2000 ; Baumann, 2001). Production of thinner leaves resulting from shading is a morphological adaptation, whereas SLA is important in modelling for light competition (Kropff and Spitters, 1992 ; Cavero et al., 2000,
Spitters et al., 1989). Accounting for higher SLAvalues resulting from shading was only partly able to explain the underestimation in simulated competitiveness of $S$. hamata. Shading can also create an alteration of vertical leaf area density profiles with a higher concentration of leaf area in the top of the canopy due to competition for light (e.g., Cavero et al., 2000 ; Baumann, 2001). For $S$. hamata more studies are needed to further characterize its morphology as well as its plasticity in response to light stress.

In the relay intercropping systems of rice-cover crops, accumulation of legume biomass for fallow improvement has to be realized under the condition that current rice yield is hardly reduced. Experimentation and simulation showed that the attainable legume biomass depends on the combined effects of sowing time of the cover crops, the competitive ability of the cover crop species and the rice cultivar. Compared to early introduction, late introduction of the cover crop had little effect on rice production, but at the same time accumulation of legume biomass was small and consequently only small amounts 
of nitrogen were added to the system. Delaying the sowing time has previously been identified as an important management factor in relay cropping systems, as it reduces the competitiveness of the relay-planted species (Gilbert, 1998 ; Fischler and Wortmann, 1999). A clear difference in rice production as affected by introduction of the two legumes was observed. Simultaneous sowing of rice and $C$. cajan resulted in a complete loss of the rice crop, whereas at this introduction time the combination with S. hamata still yielded around $35 \%$ of the control yield. Also at later introduction times of the legumes the more competitive character of C. cajan was reflected in a higher loss in rice yield and a concurrent higher legume biomass production. Analysis with the competition model indicated that the differences in competitive ability between both species could largely be explained by their marked differences in early height growth rate and maximum plant height. By plotting grain yield loss against produced legume biomass the two prerequisites for a successful relay cropping system are directly related. It then showed that identical results could be obtained by using either one of the legume species. The lower competitive ability of $S$. hamata could be compensated by earlier introduction of this legume in the rice crop. At moderate levels of rice yield loss, differences in introduction time of both species of about two and a half weeks were required to obtain similar results. The length of this period was partly due to a 4-day-delay in time of emergence for $S$. hamata. This result clearly reflects the principle of competition, where two or more species are contesting for the same resources and as a result the growth of one species will be at the cost of the other species. Observed differences between the performances of the two rice cultivars in this relay cropping system can be explained by means of the same principle. At similar introduction dates of a legume, rice yield reduction of the more competitive $\mathrm{V} 4$ was found to be smaller, whereas less legume biomass was produced. In this case later introduction of legumes in the less competitive WAB56-50 gave comparable results. On average a delay of 5 days compensated for the lower competitiveness of WAB56-50. Consequently, one of the main conclusions of this study is that in the rice relay cropping system under study, the attainable legume biomass production at rice maturity is nearly completely determined by the level of loss in rice grain yield that is considered acceptable. This reflects the nature of competition, as the production of legume biomass is at the cost of rice production. This conclusion is irrespective of selected legume species or choice of rice cultivar, taking into account that any combination of rice cultivar and legume species requires its own specific legume introduction time. Furthermore, it is also obvious that at low levels of rice yield reduction only marginal amounts of legume biomass will be obtained at rice maturity.

\section{MODEL ANALYSIS OF THE CROPPING SYSTEMS}

In the savanna zone of West Africa, residual soil moisture after maturity of the rice crop allows for an extended growth period of the relay crop. Simulation studies in the period 3 weeks after rice harvest showed that the performance of $C$. cajan surpasses that of $S$. hamata, an observation in line with earlier reported experimental results, where the legumes were allowed to grow for an additional period of 7-10 days after rice maturity (Akanvou et al., 2002). Model analysis showed that a combination of factors was responsible for this effect. First because the difference in LAI became smaller, and secondly because the absolute values of LAI were getting higher, through which the additional light interception for each additional unit of leaf area became smaller. The weaker competitive ability of $S$. hamata necessitates an earlier introduction of this species, resulting in a phenologically older crop at rice maturity. Particularly in combination with the shortduration character of $S$. hamata, this resulted in the relatively poor production of this species in the additional period of growth. It was concluded that the use of competitive legumes in rice cover legume intercropping systems was more promising than the use of more weakly competitive ones. This conclusion can be made more specific now, as the model analysis suggests that only the combination of poor competitiveness and short duration is unfavourable in this particular system.

In the simulation analysis, temperature and light were used as the main driving variables. Nitrogen and water were not explicitly accounted for, although competition for nitrogen between rice and legume could not be precluded, and water availability obviously played an important role, as it largely determines the length of the additional growth period. Nevertheless, the simulations greatly helped in developing a better insight in the complex rice-relay cropping system and particularly in identifying the main 
options for optimizing this system. Given the fact that only small reductions in current rice grain yield will be tolerated by farmers, main legume biomass production and concurrent $\mathrm{N}$ accumulation have to come from the growth period after rice maturity, making use of residual soil moisture. One way of improving the rice relay cropping system seems the shortening of the rice growth period, which in this case will lengthen the rice-free growth period of the legumes. Analysis of rice production in various environments showed, however, that in most situations selecting for rice cultivars that yield highest in a given environment has resulted in selection of cultivars with an optimum duration (Yin, 1996). This suggests that use of cultivars with shorter duration than commonly used might lead to a reduction in actual yield. A less risky way would be the selection of suitable legume species. The current study strongly suggest that desirable characteristics of such legume species will be related to an optimum utilization of the growth period after rice harvest, like a fast growth rate and drought tolerance.

\section{CONCLUSION}

Relay intercropping legume cover crops in upland rice can create considerable yield loss in rice depending on the time of legume establishment and the competitive ability of the species. On average rice yield was reduced from 0 to $63 \%$ by S. hamata while C. cajan created up to 100 $\%$ yield loss depending on the introduction time. Although C. cajan was more competitive than $S$. hamata, comparable amounts of biomass at rice maturity were produced if the level of rice yield loss was predefined. Under growth conditions of the savanna zone of West Africa, available soil moisture after maturity of the rice crop allows for an additional period of growth of the cover crop of around three weeks. The simulation study identified the crucial role of this additional growth period for realizing a reasonable amount of legume biomass at the cost of marginal reductions in rice yield. The lesser performance of $S$. hamata in the period following rice maturity was attributed to the difference in phenology, combined with the short-duration character of this species. Based on the gained insight in the rice-legume intercropping system in the savanna zone of West Africa it was concluded that this system would benefit most from rapidly growing, drought-tolerant legume species. Finally, using shorter duration rice cultivars that, due to early rice harvest, would lengthen the growing period of the cover crop in a non-competitive environment was identified as an option that requires further investigation.

\section{ACKNOWLEDGEMENTS}

The authors are grateful to the Centre National de Recherche Agronomique (CNRA) of Côte d'Ivoire, WARDA and Wageningen University for co-funding this research work and to reviewers who helped improve the paper

\section{REFERENCES}

Akanvou (R. K.). 2001. Quantitative understanding of the performance of upland rice - cover legume cropping systems in West Africa. PhD Thesis, Wageningen University (the Netherlands), 149 p.

Akanvou (R.), (M. J.) Kropff, (L.) Bastiaans and (M.) Becker. 2002. Evaluating the use of two contrasting legume species as relay intercrop in upland rice cropping systems. Field Crops Res. $74: 23$ - 36.

Bastiaans (L.), (M. J.) Kropff, (N.) Kempuchetty, (A.) Rajan and (T. R.) Migo. 1997. Can simulation models help design rice cultivars that are more competitive against weeds? Field Crops Res. 51 : 101 - 111.

Baumann (D). 2001. Competitive suppression of weed in a leek-celery intercropping system. An exploration of functional biodiversity. Ph.D. Thesis, Wageningen University (the Netherlands), 190 p.

Bouman (B. A. M.), (H.) Van Keulen and (H. H.) Van Laar. 1996. The 'School of de Wit' Crop Growth Simulation Models : A pedigree and historical overview. Agric. Sys. 52 : 171 - 198.

Cavero (J. C.), (L.) Zaragoza (L.) Bastiaans (M. L.) Suso and (A.) Pardo. 2000. The relevance of morphological plasticity in the simulation of competition between maize and Datura stramonium. Weed Res. 40 : 163 - 180.

Cousens (R.). 1985. An empirical model relating crop yield to weed and crop density and a statistical comparison with other models. J. of Agric. Sci. $105: 513-521$. 
Fageria (N. K.). 1992. Maximizing crop yields. Marcel Dekker, Inc, New York. 312 p.

Fischler (M.) and (C. S.) Wortmann. 1999. Green manure research in eastern Ouganda : Agronomic performance and farmers' perceptions. Agrof. Sys. $47: 123-138$.

GENSTAT 5. Release 4.1. 1998 Fourth edition Lawes Agricultural trust. IACRRothamsted, UK.

Gilbert (R.). 1998. Undersowing green manures for soil fertility enhancement in the maizebased cropping systems in Malawi. In : Waddigton (S. R.), (H. K.) Murwira, (J. D. T.) Kumwenda, (D.) Hikwa and (F.) Tagwira. (Eds.). Soil fertility research for maizebased cropping systems in Malawi and Zimbabwe. SoilFertNet / CYMMITZimbabwe, Harare, Zimbabwe : pp 73 - 80.

Goudriaan (J.) and (H. H.) Van Laar. 1994. Modelling potential crop processes. Textbook with Exercices. Kluwer Academic Publishers, Dordrecht the Netherlands, $238 \mathrm{p}$.

Hawkins (A. F.). 1982. Light interception, photosynthesis and crop productivity. Outlook Agric. $11: 104$ - 113.

Kropff (J. M.) and (H. H.) Van Laar. 1993. Modelling Crop-weed interactions. Cab International Publishers, Wallingford, UK, 267 p.

Kropff (M. J.), (H. H.) Van Laar and (R. B.) Matthews (Eds.). 1994. Oryza1 An ecophysiological model for irrigated rice production Wageningen, the Netherlands, $110 \mathrm{p}$.

Kropff (M. J.) and (C. J. T.) Spitters. 1991. A simple model of crop loss by weed competition from early observations on relative leaf area of the weed. Weed Res. $31: 7-105$

Kropff (M. J.) and (C. J. T.) Spitters. 1992. An ecophysiological model for interspecific competition, applied to the influence of Chenepodium album L. on sugar beet. I. Model description and parameterization. Weed Res. $32: 437$ - 450.

Liebman (M.) and (E.) Dyck. 1993. Crop rotation and intercropping strategies for weed management. Ecolog. Applications 3(1) : $92-122$.

Spitters (C. J. T.). 1983. An alternative approach to the analysis of mixed cropping experiments. 1. Estimation of competition effects. Netherlands Journal of Agric. Sci. $31: 1-11$.

Spitters (C. J. T.), (H.) Van Keulen and (D. W. G.) Kraalingen. 1989. A simple and Universal Crop Growth Simulator: SUCROS87. In : (R.) Rabbinge, (S. A.) Ward and (H. H.) van Laar (Eds.). Simulation and systems management in crop protection, Pudoc, Wageningen : pp147 - 181.

Vandermeer (J.). 1989. The ecology of intercropping. Cambridge University press, Cambridge, $237 \mathrm{p}$.

Yin (X.). 1996. Quantifying the effects of temperature and photoperiod on phenological development to flowering in rice. PhD thesis, Wageningen University, (the Netherlands), $173 \mathrm{p}$.

Willey (R. W.). 1979. Intercropping-its importance and research needs. Part 1. Competition and yield advantages. Field Crop Abst. 32 : $1-10$. 